\title{
Somogy megyei népdalok és gyermekjátékok egy Győrött őrzött kéziratban
}

\author{
PERGER GYULA \\ Xántus János Múzeum, \\ H-9022 Győr, Pf. 93., e-mail: perger.gyula@gymsmuzeum.hu
}

\begin{abstract}
Perger, GY.: Folksongs and children's games from Somogy County in a hand-written manuscript from Györ

Abstract: The folk poetry of Somogy County have been known by the public from the end of the $18^{\text {th }}$ century. After the initial sporadic publications the methodical collecting work of the folksongs and children's games started at the end of the 19th century. Béla Vikár introduced a considerable part of the folk traditions of the region in a complete volume of the Hungarian Folklore Collection series. In the $20^{\text {th }}$ century a great number of collections and monographs were dedicated to this topic, however, a part of the unpublished collections were unfortunately lost. The presently published folklore collection from Somogy County has been found recently in the Xántus János Museum of Győr, which was a part of the former Benedictine Historical Collection.
\end{abstract}

Keywords: folksong, children's games, hand-written collection.

A Magyar Népköltési Gyűjtemény Somogy megyei kötetének utószavában, Vikár Bélának - a gyermekjátékok és dalok kapcsán tett - megjegyzése szerint „ebből a fajtából, melyet Kiss Áron mintaszerü és gazdag gyűjteményben dolgozott fel, újat már alig találhatunk. A mi e részben még akad, legfölebb mint változat jöhet figyelembe." ${ }^{\prime}$ A gyűjtemény kiadása óta eltelt évszázadban ugyanakkor - akár a fenti tárgykör tekintetében is - számos új eredménnyel gazdagodott Somogy megye folklór archívuma, s a millecentenárium évére elkészült Szapu Magda hézagpótló összeállítása is. ${ }^{2}$ Igaz, már e kötet bevezető tanulmányából kiderül, hogy a Kiss Áron által kezdeményezett gyűjtés publikálatlan somogyi anyagának nyoma veszett, csakúgy, mint a Gönczi Ferenc monográfiájához készült illusztrációknak. ${ }^{3}$ Éppen ezért örvendetes, hogy időről-időre, eddig ismeretlen, lappangó gyüjtések, adatok is napvilágra kerülnek.

$A z$ 1859-ben hivatalosan is múzeummá nyilvánított győri Szent Benedek rendi régiségtár gyűjteménye 1949-ben, az iskolák államosítása révén került Győr városához, majd Győr-Moson-Sopron megyéhez. Az egykori bencés gyűjtemény adta és adja a győri Xántus János megyei múzeum törzsanyagát. Bár a leltárak és leírókartonok az 1960-as évek elejére elkészültek, a „vegyes iratanyag” tételes feldolgozása csak az elmúlt években kezdődött meg. A T. 19. IX. jelzésű dossziéban - számos versmásolat és eredeti kézirat között - egy néprajz feliratú borítékban, szárazpecsétes papírlapokon somogyi vonatkozású kézirat található. ${ }^{4} \mathrm{~A}$ teljes ív négy oldalára - a címjelzés szerint - Gyermekdalok. (Somogyból), míg a fél ívnyi papír két oldalára Népda-

\footnotetext{
1 Vikár 1905. 440.

2 Szapu 1996.

3 Szapu 1996. 9-22.

4 Xántus János Múzeum Történeti Gyüjteménye. A dosszié, annak címleírása szerint, „különféle kéziratok”-at tartalmaz.
}

lok szövegei kerültek. Bár a lejegyző „Holics Gy.” neve szerepel a kéziraton, ${ }^{5}$ sem az adatközlők, sem a gyűjtés pontos helyét nem ismerjük. A papír és a tinta anyaga alapján, a lejegyzés a 19. század végén, a 20. század elején történhetett.

A Népdalok címü kézirat első darabja a közismert „Elvágtam a ujjam, jaj de fáj” kezdetű ének változata. A második, részben azonos szövegvariánssal, már a Magyar Népköltési Gyüjteményben is helyet kapott, a „Balladák és rokonnemüek” között. A Holics kéziraton szereplő szövegről ugyanaz mondható, amit Vikár Béla a somogyi gyűjtésben Bogár Jancsi címmel közölt balladához füzött: „A költemény kétségkívül hiányos; a két versszak eredetileg aligha tartozott össze, vagy másmás költeményből valók, vagy éppen köztük hiányzanak az egykori összekötő kapcsok."6 A harmadik - teljesnek tekinthető szöveg - egy Angyal Bandi személyéhez kötött ballada.

A Gyermekdalok szövegeit tartalmazó ív négy gyermekjátékdalt, illetve játékleírást tartalmaz. Ezek közül csupán egy, a hidas játék ismert az eddig publikált somogyi gyüjtésekből. A játék - több Somogy megyei változattal - szerepel Kiss Áron gyűjteményében, ${ }^{7}$ részleges játékleírással a Magyar Népköltési Gyűjteményben, ${ }^{8}$ Gönczi Ferenc somogyi gyermekjátékai ${ }^{9}$ és Együd Árpád gyűjtéseiben is. ${ }^{10} \mathrm{~A}$ Holics által lejegyzett változat mindezeknél bővebb, $s$ teljes játékleírást is mellékel. $A$ kézirat három másik darabja eddig „ismeretlen” csúfoló, illetve gyermekjáték-dal.

Az alábbiakban a győri múzeumban őrzött kéziratokat betühíven közöljük:

\section{Népdalok ${ }^{11}$}

I.

Elvágtam az ujjom, jaj de fáj

Elfolyt piros vérem jaj de kár

Czédrus fa levele gyógyítsd, gyógyítsd gyógyítsd meg

Kedves kis angyalom csókolj meg.

5 A bencés névtár tanúsága szerint Holics vezetéknevű nem volt a rendtársak között. Az egykori diákok egyike ugyanakkor Holics Gyula, aki Somogyi néven a gimnázium önképző körének folyóiratában is rendszeresen publikált. Holics 1866-ban érettségizett Györött. 1848 május 18-án született Göllén. Az iskolai anyakönyv szerint édesapja Mernyén volt kasznár.

6 Vikár 1905. 386., 13. szöveg, 22-23.

7 Kiss 1891. 213-218.

8 Vikár 1905. 255-256.

9 Gönczi 1949. 31-33

10 Szapu 1996. 140-148. további adatok ismertetésével.

11 Mellette zárójelben - ugyanazon kéz által - ceruzával írva: Somogyból 
Nyítva va a város kapuja

Hínak engem oda verbungra

Nem megyek én oda verbung, verbung verbungra Inkább leszek lovas katona.

Patalonban ${ }^{12}$ lakik a vicebíró

Vájja ki a két szemét a holló

Beiratott engem katonának

Sírva hagytam az édes anyámat.

II.

Patkó Pista kisétált az erdőre,

Vágott tetejü kalap volt a fejében,

Fújja a szél duhaj ingét gatyáját,

Föld emészsze meg a karcsu derekát;

$$
x x x
$$

Kincsem feleségem

Van e apró pénzed?

Sem öreg sem apró,

Elvitte Patkó, elvitte Patkó.

[verso]

III.

Ha betekintsz a dadai csárdába

Bort iszik a szegény legény bujába

Míg a csárdásné jóféle italt hoz

Addig lovát megköti az ágashoz

„Áldjon Isten!" szóval iszik egy hajtást

$S$ bő ingéből megkinálja a pajtást

S ezzel félre vágja pörge kalapját

S eldalolja Angyal Bandi notáját

Tisza felől beborúlt az égalja

Angyal Bandi a babáját siratja

Hej! de sok szegény legény azt gondolja

Övé a lány ha egyszer megcsókolja.

Ne buslakodj Angyal bandi babádon

Nem áll meg a pille minden virágon

Bár szép volt a szölke kislány, feledd őt

Ad az Isten néked még szebb szeretőt.

\section{Gyermekdalok. (Somogyból)}

$$
\text { I. }
$$

Kisleányok vagy fiúk is, leguggolva elkezdenek táncolni, és ezt éneklik:

Muc, muc, mucirka

Jáger kati, julinka

Lám megmondta a szarka

Hoszabb legyen a farka

Mint a bíró botja.

12 Azonos tollal, a lejegyző betűivel, csillaggal jelzett lábjegyzet: Patalon, helység Somogy megyében
Ezután valamely emelkedettebb helyre mennek föl és onnét leugranak; de leugrás elött ezt éneklik, kezöket lóbálva:

Hinca, barinca

Karácsonyi katica

Ki ne törjék az én lábam

Sem apámé, sem anyámé

Csak a bíró botja.

Midőn ezen utolsó szót „botja” kimondják, épen akkor ugranak le.

II.

A leánykák, a gyermekeket boszantván ezt éneklik:

Gyerekek!

Ördögi seregek

Mi az ebédetek?

Három búbos béka,

Tarka kutya combja,

Aki aztat megeszi,

Holnap délig aluszik,

Mint a döglött róka!

A leánykák pedig éneklik önmagukra:

Leányok!

Angyali seregek

Mi a vacsorátok?

Három piros alma,

Kövér disznó combja,

Aki aztat megeszi, Holnap délig aluszik,

Mint a nyitott rózsa!

A gyerekek a leányokra ezt éneklik

Leányok!

Földi boszorkányok

Mi a vacsorátok?

Zsidó aszszony „májája”,

Egy töröknek zuzzája,

Aki aztat megeszi

Holnap délig aluszik,

Mint a döglött róka!

A gyermekek önmagukra azt éneklik, mint a leánykák.

[Gyerekek!

Angyaki seregek

Mi a vacsorátok?

Három piros alma,

Kövér disznó combja,

Aki aztaz megeszi,

Holnap délig aluszik,

Mint a nyitott rózsa!]

III.

Ezt körbe állván egy leányka énekli:

Itthon vagy e hidasmester?

Itthon vagyok csak most jöttem,

Ereszsz átúl a hidadon,

Nem eresztlek, mert le szakad, 
EGY GYÖRÖTT ÖRZÖTT KÉZIRATBAN

Ha leszakad megrakatom,

Kivel tudnád megrakatni?

Aranypénzzel kősziklákkal

Hol vennéd az aranypénzt és kősziklákat?

Isten adná jobb kezéből.

Ezután ha megengedi neki a hidas mester az ezeket éneklö leánynak, hogy átmehet a hídon, akkor a hidas mester ezt énekli:

Bujj, bujj zöld ág

Zöld levelestől

Nyitva vagyon aranykapú

Csak bujj átúl rajta ...

Ezután ezt éneklik:

Ispiláng, ispiláng

Ispilángi rózsa!

Rózsa volnék, piros volnék

Pénz volnék csörögnék

Karika volnék fordúlnék,

Zöld selyem rostja

Piros karmazsinja

Szeder szemű kis Lórika (vagy akárki)

Fordulj angyal módra.

Akit megneveznek annak perdülni kell, és a kör közepén megállani a többi pedig ezt énekli:

Haj szénája szénája

Széna szakadékja

Abban vagyon egy kis leány

Kerék kisleányka!

Adsza kezed édesem

Másikat is kedvesem

Húzd rá cigány a nótát

Ne sajnáljad a hurját

Megadom az árát.
Midőn ezt éneklik „adsza kezed édesem” egy leány bemegy a körbe lévőhöz, a többiek pedig ezt éneklik:

Adjon Isten lassu esőt,

Mossa öszve mindakettőt.

haj szénája szénája

Széna szakadékja.

IIII.

Szintén kis gyermekek és leánykák éneklik ezt is, játék közben, a gazdaszszonyokat utánozva.

Óh én édes molnárom

Óh én édes molnárom, nárom, molnárom nárom, molnárom

Örlesd meg a buzámat,

Örlesd meg a buzámat, zámat, buzámat, zámat, buzámat;

Abból süssünk kalácsot,

Abból süssünk kalácsot, lácsot, kalácsot, lácsot, kalácsot.

Abból adjunk szegénynek

Abból adjunk szegény legénynek, szegény legénynek, legénynek;

Akkor mondja „tambugye”

Akkor mondja „tambugye, bugye, tambugye bugye záplatye."

Holics Gy.

\section{Irodalom}

GönCZI F. 1949: Somogyi gyermekjátékok. - Szabó Pál Z. (szerk): A Dunántúli Tudományos Intézet Kiadványi 12. Kaposvár Kıss Á. 1891: Magyar gyermekjáték-gyüjtemény. Budapest
SzAPU M. 1996: Gyermekjátékok. Énekes-táncos, szöveges, mozgásos és sportszerü népi játékok Somogyban. - Szapu M. (szerk): Válogatás Együd Árpád néprajzi gyưjtéseiből 3. Kaposvár

VIKÁR B. 1905: Somogymegye népköltése. - Vargha Gy. (szerk): Magyar Népköltési Gyüjtemény. Uj folyam VI. kötet. Budapest 
302

PERGER GYULA

Gyermek dalok. (Somugy bol/

ofisteányoh vagy fiuk is, leguggolvo etherdeneh táncolni, es ert éneklik:

Thuc, muc, mucirka

Yáger kati, julinka

Lim megmondtax a frarka

Clasabb legyen a farra

atlint a biró botyo.

irutain valamely emelkedette b6 helyre memek fil is omét leugranak, de leugrás elott ert éneklik, Nerö ket lóbbalwa:

Ilinca, barinca

Trarácsonyi katica

Sî ne torjét arénlábarn

Lem apámé, sem anyámé

Coak a biró botion.

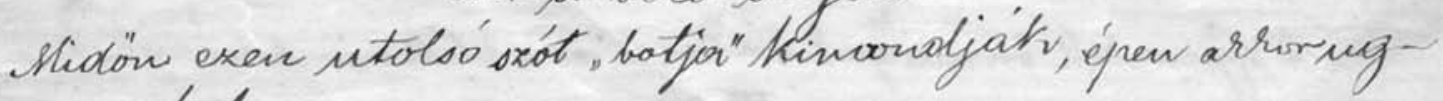
manak le.

II $^{\text {is }}$

A lianytiák, a gyemerered bosxon traver ext énerlik:

syerekek!

Ördïgi seregek,

ati ar ebidetek?

Slarom bübos béka,

Tarka futyo combjo,

Aki artat megesei,

Folnap délig a woxik,

Shint a digglott nika. 
SOMOGY MEGYEI NÉPDALOK ÉS GYERMEKJÁTÉKOK

303

EGY GYÖRÖTT ÖRZÖTT KÉZIRATBAN

At teánytiak peodig énerlik örmagut. ra:

Leányok!

Angyali seregek

Mis a vacsoratok?

Larom piras alma.

Mövés disenó combja,

A fi artat megessi,

Holnap delig alusits,

Hint a miloto rórsa!

Agyermerek a teanyotema exténerlik

Leanyole!

Földi baszorkányok

thi a vacsorátok?

Zsidó assszony "májäja,"

loy tiö̈knet xurrájo,

Ifi artat megosci

Llohap dilig a uscik,

Mint a dïglïnt nóka!

of oyemerek önmaguk ra art érertik, mit deamytha'k, sul tionke álvamegy lémykak énercix:

Ithon vagye hidasmester?

stthon waqyok sak most jöttew,

vressos átúl a hidadon,

Nem eresatlek mert le frarad,

La leszarad megnaratom,

thivel tudnad megnarativ?

Aranypienrel Nósithirral

Iloluerméd arsaranypénstés ko"fik-

la'rat? 
304

PERGER GYULA

Isten aduń jobb kociboll.

Crutain ha megengedi nerd hidpsosester

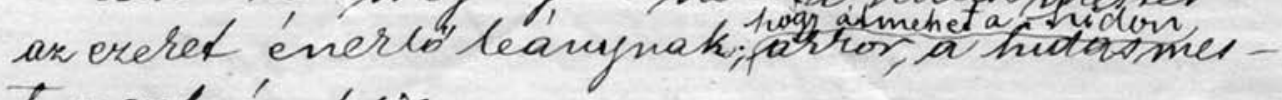
ter ort énetew:

Suyj, bujj iold oig

Lold levelestól

Nyitwa vagyon aranykajin

Csar bujf átuil najtor...

Exutan exs éneklik:

Spritáng, ispitaing

Mspilángi rórsa!

rórsa volnék pirospolnek

Pénk volnét csörogrék

Harika volnék fondúlnét,

Liold selyem rastja

Pivos harmaxiniza

Sxeder sxemin kis Lórika vagatárki|

fordulj angyal mo Dra.

Ak't megnevernek amak fondülwi kell, is a kör hörepien megaltani a tobbi podig ont ónerti:

Faj stenaja sténája réna sxaradélya

Afban vagyokn egy kis leány Herik kisleamyka.'

Adsza kared édesem

Nhósitat is kedvesems

Fhird ná ciqány a nótat

Me sajnailad a, hurjat.

Nhegadom ar árat. 